\title{
Cases of apparent enclisis on past participles in Romance varieties
}

\author{
Anna Cardinaletti \\ Università Ca' Foscari Venezia \\ cardin@unive.it
}

Received: 20-04-2015

Accepted: 09-07-2015

\begin{abstract}
This paper deals with cases of apparent enclisis on past participles in North-Western Italian varieties. It is claimed that these cases do not involve clitic pronouns, but weak pronouns in the sense of Cardinaletti and Starke (1999). Both syntactic and morphophonological evidence is discussed. Some varieties display both proclitics and postverbal weak pronouns and use them in different syntactic contexts. Other varieties lack clitic pronouns in their lexicon altogether and only display weak pronouns (alongside strong pronouns), similarly to what happens in e.g. Germanic languages.
\end{abstract}

Keywords: clitic pronouns; weak pronouns; Romance; Italian/Piedmontese varieties.

\section{Table of Contents}

\section{Introduction}

2. Clitic vs. weak pronouns

3. Franco-Provençal Valdôtain dialects
4. Piedmontese dialects

5. Borgomanerese

6. Conclusions

References 


\section{Introduction}

In most Romance languages, sentences with auxiliaries (e.g., active sentences with compound tenses and passive sentences) are contexts of obligatory clitic climbing: clitic pronouns do not attach to the past participle but occur in the high clitic position attached to the auxiliary:
a. ${ }^{*}$ Ho vistolo.
[I] have seen-him
b. L' ho visto.

[I] him have seen

'I have seen him.'

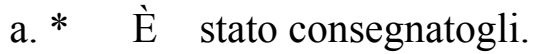
[it] has been delivered-to.him
b. Gli è stato consegnato.
[it] to.him has been delivered
'It was delivered to him.'

This paper discusses some apparent exceptions to this very robust crossRomance generalisation. In languages such as Franco-Provençal Valdôtain dialects, cases like (3) are attested in which the clitic pronoun lèi 'to.him' follows the past participle in a finite clause (Kayne 1991:660, which reports data from the Aosta dialect described in Chenal 1986:340):

$$
\begin{aligned}
& \text { L' an tot portà-lèi vià. } \\
& \text { they have everything carried-to.him away } \\
& \text { 'They have taken everything away from him.' }
\end{aligned}
$$

Some of the cases displaying post-participle clitics, such as those in (4) found in the Borgomanerese dialect studied by Tortora (1997), (2002), (2014), also seem to represent a counterexample to a second robust cross-linguistic generalisation, which can be represented as in (5)-(6):

(4) I o vüst piö-lla.

I have seen anymore-her

'I haven't seen her anymore.'
a. clitic XP verb
b. clitic DP verb
a. * verb XP clitic
b. * verb DP clitic

In the general case, proclitics can appear independently of the verb and be separated from it by other lexical material, as in (5), while postverbal clitics are always adjacent to the verbal host, (6) (see Kayne 1991:657,n.27 and Rizzi 2000:117f for Romance languages, and Starke 1993 for Slavic languages). In (5) and (6), two possible situations are schematized: the intervening material is either an adverbial XP or the subject DP. As (4) shows, in Borgomanerese, the postparticiple pronoun appears enclitic not on the verb but on an adverb, instantiating 
(6a). As we will see in (27c) below, configuration (6b) is also found in this dialect.

This paper aims at showing that (3) and (4) can be analysed as apparent cases of enclisis on past participles. They can in fact be taken to involve weak pronouns (in the sense of Cardinaletti and Starke 1999), which are independent of the verb and are expectedly found in lower positions in the clause than clitic pronouns. The cases in (3) and (4) are therefore only apparent counterexamples to the two cross-linguistic generalisations mentioned above, a welcome result given current hypotheses on language variation as being related to properties of lexical items and not on general syntactic properties of the languages.

The paper is organised as follows. In section 2, the properties which distinguish clitic from weak pronouns are presented, based on Cardinaletti and Starke's (1999) generalisations. In section 3, data from Franco-Provençal dialects are discussed, and the proposal that postverbal pronouns are weak is presented and supported by both syntactic and phonological properties. In Section 4, the analysis is extended to the Piedmontese dialects discussed by Burzio (1986). Section 5 is devoted to Borgomanerese, where language-internal morphophonological evidence seems to support the proposal.

\section{Clitic vs. weak pronouns}

In this section, we review the evidence provided by Cardinaletti and Starke (1999) to distinguish two distinct classes of non-strong pronouns, namely clitic and weak pronouns. We discuss here the different phonological and syntactic properties and the common semantic properties which are relevant to the understanding of the data analysed in the following sections.

On the phonological side, clitic pronouns are well-known not to bear word stress and to consist of one (light) syllable, while weak pronouns can bear word stress and be bisyllabic. See e.g. the Italian dative weak pronoun loro 'to.them', pronounced ['lo:ro], which is bisyllabic and where vowel lengthening occurs in the stressed syllable.

On the syntactic side, weak pronouns differ from clitic pronouns in that they do not enter clitic clusters. As shown in (7) for restructuring verbs in Italian, two clitic pronouns such as $m i$ 'to.me' and lo 'him' must form a clitic cluster, in either enclitic (7a) or proclitic position (7b) (see Rizzi 1982). ${ }^{1}$ This is not the case in (8), where the clitic pronoun $m i$ 'me' and the weak pronoun loro 'to.them' do not cluster and appear on opposite sides with respect to the verb (cf. Cardinaletti 1991:138):

a. Voleva presentarmelo ieri me-le.
[he] wanted [to] introduce-to.me-him yesterday
'He wanted to introduce him to me yesterday.'

I take the clitic cluster in (7a) to occupy a "low" clitic position above VP (Cardinaletti and Shlonsky 2004). Note that not all clitic combinations are possible in enclisis (see Cardinaletti 2008, 2010 for discussion). 

b. Me lo voleva presentare ieri me lo.
[he] to.me him wanted [to] introduce yesterday
'He wanted to introduce him to me yesterday.'
c. *Mi voleva presentarlo ieri.
d. *Lo voleva presentarmi ieri.

Mi voleva presentare loro ieri. [he] me wanted [to] introduce to.them yesterday

'He wanted to introduce me to them yesterday.'

The same split configuration is found with compound tenses: the clitic pronoun $m i$ occurs in the high clitic position, as in (1), while the weak pronoun loro follows the past participle, as in (8):

Mi ha presentato loro ieri.

[he] to.me has introduced to.them yesterday

'He introduced me to them yesterday.'

Like all non-strong (or deficient) pronouns, Italian dative weak pronoun loro must move to the left to a position which precedes the direct object and may follow adverbs like mai 'never' (Cardinaletti 1991):
a. Maria ha dato loro un libro tore. Maria has given to-them a book
'Maria gave them a book.'
b. Non ho dato mai loro un libro lore. [I] not have given ever to.them a book 'I never gave him a book.'

Loro may also be separated from the verb by a postverbal subject pronoun. See (11), which is possible alongside with Parlerò loro io:

(11) Parlerò io loro.

will.speak I to.them

'I will speak to them.'

The choice between the two classes of pronouns is ruled similarly to the choice between a non-strong and a strong pronoun, i.e., the smallest form is chosen whenever possible. Whenever a clitic and a weak form compete, the clitic form takes precedence over the weak form. The Choice generalisation can be formulated as in (12) (see Cardinaletti and Starke 1999:174-5 for discussion):

$$
\text { clitic }<\text { weak }<\text { strong }
$$

This generalisation is clearly illustrated by declarative vs. imperative sentences in French. In the declarative sentence in (13a), the possibility of the clitic pronoun me blocks the merger of the weak pronoun moi; in the imperative sentence in (13b), the situation is reversed: clitic pronouns are impossible, and 
weak pronouns are merged instead (Cardinaletti and Starke 1999:221,n.32; see Ordóñez and Repetti 2014 for similar facts in Southern Italian dialects):

(13) a. Il me donne / *Il donne moi un livre. he to.me gives / gives to.me a book 'He gives me a book.'

b. *Donne-me / Donne-moi un livre! give-to.me / give-to.me a book

'Give me a book!'

c. Donne un livre à moi! give a book to me 'Give a book to me!'

As for morphology, consider the generalisation in (14) discussed in Cardinaletti and Starke (1999:174), according to which the three forms are ranked with respect to their lexical form: strong pronouns are more complex than weak pronouns, which are more complex than clitic pronouns:

clitic $<$ weak $<$ strong

The Italian and French weak forms loro and moi in (10) and (13) are clearly smaller than the corresponding strong pronouns a loro and $\grave{a}$ moi and bigger than their clitic counterparts gli and me, respectively. In some analyses, the different forms correspond to a different morphological internal structure. Clitic pronouns such as Italian $m i$ are taken to be monomorphemic elements and to contain an epenthetic vowel /i/ (cf. Kayne 2000:135, Cardinaletti 2008, 2010). The final vowel $e$ in strong Italian pronouns like $m e$ (as in Ha visto solo me ' $\mathrm{He}$ has seen only me') is instead taken to be part of their lexical entry. Kayne (2000) suggests that $e$ in $m e$ is a morpheme realising singular number, on a par with the sequence $o i$ in French weak/strong pronoun moi (see $(13 b, c)$ above). For the different morphological make-up of clitic and weak pronouns in Southern Italian dialects, which goes in the direction of (14), see Ordóñez and Repetti (2014). Complexity may also show up in another way. In some Germanic varieties, weak pronouns are more complex than clitic pronouns in displaying initial vowels, which are called "support" morphemes in Cardinaletti (1994) (cf. Cardinaletti and Starke 1996).

Finally, consider the semantic properties of pronouns. Strong personal pronouns may only refer to human entities, non-strong pronouns are free to refer to both human and non-human entities. A verb that implies a non-human object, such as comprare 'buy', gives ungrammatical results with a strong pronoun (15a) and is only compatible with a clitic pronoun $(15 b) .{ }^{2}$ On a par with clitic pronouns,

$2 \quad$ See Kayne (1975:91); Jaeggli (1982:41); Rizzi (1982); Berendsen (1986:38-39); Schroten (1992); Corver and Delfitto (1999); Cardinaletti and Starke (1996), (1999) among others. This restriction does not apply to demonstrative pronouns, which can have non-human referents: Je ne connais / achète que celui-là 'I don't know / buy [other] than that one'. 
weak pronouns can have both human and non-human referents (16) (from Cardinaletti and Starke 1999:149):

a. Non conosco / * compro che lui. [I] not know / buy [other] than him 'I only know him.'

b. Lo conosco / Lo compro.

[I] him/it know / [I] it buy

'I know it/him / i buy it.'

(16) Non metterò mai loro il cappuccio.

I not will.put ever to.them the cap/pen-top

'I will never put the cap / the pen top to them.'

In what follows, we will discuss the properties of pronouns which are enclitic on the past participle in North-Western Italian varieties. There is some evidence to argue that these pronouns are not clitic, but weak.

\section{Franco-Provençal Valdôtain dialects}

In Franco-Provençal Valdôtain dialects, a clitic pronoun can appear enclitic on the past participle (Kayne 1991:660, which reports data from Chenal 1986:340):

$$
\mathrm{L}^{\prime} \text { an tot portà-lèi vià. }
$$

they have everything carried-himdat away

'They have taken everything away from him.'

The following observations suggest that the exceptionality of the pattern in (17) is only apparent.

First, orthography shows that the pronoun bears stress and contains an open "e" in a closed syllable (lei). This property is incompatible with its clitic status given that, as said above, clitic pronouns never bear word stress.

Second, these dialects allow split clitics (from Kayne 1991, who quotes Chenal 1986). In (18a), the dative pronoun $t$ 'to.you' is proclitic on the auxiliary, while the genitive pronoun nen 'of.it' follows the past participle. The same happens with the accusative lo 'it' in (18b). In this respect, these dialects differ from Italian (and other Romance languages), in which two clitics must form a cluster, see (7) above:

$$
\begin{aligned}
& \text { a. T' an- të prèdzà-nen? } \\
& \text { to.you have they spoken-of.it? } \\
& \text { 'Did they speak of it to you?' } \\
& \text { b. T' an- të deut-lo? } \\
& \text { to.you have they said-it? } \\
& \text { 'Did they say it to you?' }
\end{aligned}
$$

Third, when the pronoun can appear in either preverbal or postverbal position, the pronoun that follows the past participle - e.g. me in (19a) - is more 
complex than its proclitic counterpart, e.g. $m$ in (19b) (the data are from the village of Brusson in the Val d'Ayas, taken from Roberts 1993:330):
a. Gnunc l' a viu-me. nobody he has seen-me
b. Gnunc m' a viu. nobody me has seen 'Nobody saw me.'

That the contrast in (19) is not phonological in nature seems to be supported by the observation that all pronouns have a longer form in postverbal position, even pronouns such as ye as in (20), whose onset could in principle syllabify as a coda on the preceding verb: *douna-y (example (20) comes from Châtillon, taken from Roberts 1993:330):

$$
\begin{aligned}
& Y \text { en douna-ye ina pomma. } \\
& \text { we have given-him an apple } \\
& \text { 'We gave him an apple.' }
\end{aligned}
$$

As we will see in sections 4 and 5, this property is also found in other North-Western varieties and looks like a very general phenomenon.

These observations can be made sense of by suggesting that the postverbal pronouns in (17), (18), (19a), and (20) are not clitic but weak. As we have seen in section 2, weak pronouns can bear word stress, do not enter clitic clusters, and are more complex than clitic pronouns. ${ }^{3}$

The weak post-verbal pronouns in (17), (18), (19a), and (20) can be taken to occupy the same post-participle clausal area as the Italian dative weak pronoun loro (Cardinaletti 1991), which precedes the direct object (see (10) above). The post-participle clausal space can thus be taken to be the typical position for weak pronouns in Romance languages. ${ }^{4}$

The question that is raised by the data in (17), (18), (19a), and (20) is not why in these Romance varieties, clitic pronouns occur in a low clausal position and do not climb, but rather what prevents clitic movement to the high clausal clitic position so that a weak pronoun is used instead (see the Choice generalisation in (12) above). The question is raised particularly by those varieties in which both options are available, as shown in (19).

As pointed out by Roberts (1993), Franco-Provençal dialects display a OCL-for-SCL restriction (object clitics stand for subject clitics). That subject clitics are in complementary distribution with object clitics is clearly shown by the examples in (19), which display language-internal variation: when the subject

3 This analysis is similar to Ordóñez and Repetti's (2006), (2014) account of nonstrong pronouns in Southern Italian dialects. Based on the different morphological forms of proclitic and enclitic pronouns, they suggest that the former are clitic and the latter are weak.

$4 \quad$ Like weak pronouns in general, post-participle pronouns must evacuate their first merge position. It cannot be claimed, pace Roberts (1993:333), that they occupy "the standard complement positions". This is clear in (20), where the dative pronoun precedes the accusative argument, as in (10). 
clitic $l$ is present, as in (19a), the object pronoun follows the participle; when it is absent, as in (19b), the object pronoun is proclitic on the auxiliary. Note that when the subject is a weak pronoun, such as ou 'he' in (21), a proclitic object is possible (example from Ayas, taken from Roberts 1993:330):

Ou t' a dona euna pomma.

he to-you has given an apple

'He gave you an apple'

In Roberts' (1993) analysis, this state of affairs is captured by suggesting that the head hosting the clitic pronouns must be filled. With auxiliaries, this is usually done by the subject clitic $l$, but can be done by the object clitic when the subject clitic is absent. ${ }^{5}$

The data in (18) however show that the same complementarity is also found with object pronouns: since the subject clitic të 'they' is enclitic, an object can occur in proclitic position.

The restriction thus seems to be that in this dialect family, only one proclitic pronoun is possible on the auxiliary, either the subject or the object. This is confirmed by the minimal pair built by (18) and (22): in (18), the subject clitic $t \ddot{e}$ 'they' is enclitic, and a proclitic object can occur; in (22), when the subject pronoun $n$ 'we' is proclitic, both object pronouns lèi 'to.her' and nen 'of.it' appear postverbally (example from Roberts 1993:334):

$\mathrm{N}^{\prime}$ en prèdzà-lèi nen.

we have spoken-to.her of.it

'We spoke to her about it'

As just said, the data can be captured by the proposal that in these varieties, only one proclitic pronoun is possible with auxiliaries (two object clitics are instead allowed with simple verbs: Pierre la lèi baille 'Pierre gives it to her', Roberts 1993:332).

Also note that the subject clitic $l$ that appears with auxiliaries can cooccur with a subject enclitic in Complex Inversion, which is possible in this dialect family as it is in French (taken from Roberts 1993:336): ${ }^{6}$

$5 \quad$ Micro-variation is found as to whether the subject clitic is obligatory, optional, or absent with auxiliaries, which is however an orthogonal phenomenon with respect to the restriction discussed by Roberts (1993). In (19), the subject clitic is optional. In other dialects, it is either obligatory (as in (i)) or absent (as in (ii)).

Both examples are taken from Roberts (1993:330):

(i) Nyun y at vu-me. [Châtillon]

(ii) Gneun m'a pô vu. [St. Nicholas] nobody has seen me

'Nobody saw me.'

$6 \quad$ For an account of reduplication of subject clitics in interrogative sentences, see Cardinaletti and Repetti (2008:551-553). 
(23) Ton ommo l'est-e dza torna?

your man he is he already come.back?

'Has your man already come back?'

Another factor which interacts with the Choice generalisation in (12) is the person feature of the pronoun. Roberts (1993:330) reports that "according to Keller (1958:140), many dialects allow 3rd person pronouns to attach to the participle, while requiring other pronouns to "dislodge" the SCL". An example is provided by the contrast between (24a) and (24b) (examples from St. Nicholas, taken from Roberts 1993:330):

$$
\begin{aligned}
& \text { a. N' en baillà-lèi an pomma. } \\
& \text { we have given-to.him an apple } \\
& \text { 'We gave him an apple.' } \\
& \text { b. T' a baillà an pomma. } \\
& \text { to.you has given an apple } \\
& \text { 'He gave you an apple.' }
\end{aligned}
$$

Whatever the ultimate analysis of the OCL-for-SCL restriction, the impossibility of merging a clitic pronoun requires the merger of a weak pronoun, complying with the Choice generalisation in (12).

\section{Piedmontese dialects}

The Piedmontese dialect spoken in the Turin area, discussed by Burzio (1986), displays a similar phenomenon. As shown in (25), clitic pronouns may follow the past participle (Burzio 1986:124): ${ }^{78}$
a. A lé riva-ye dui regai.
$A \mathrm{~L}$ is arrived-there two presents
'Two presents arrived.'
b. A lé riva-me dui regai.
'Two presents arrived for me.'
A $\mathrm{L}$ is arrived-to.me two presents

The pronoun that follows the past participle displays two crucial properties: first, it is morphologically more complex than its proclitic counterpart, compare $y e$ in (25a) with $y$ in (26a) (example from Burzio 1986:122); second, the final vowel /e/ in (25) is different from the final /a/ displayed by the proclitic pronoun $n a$ in (26b-c) (examples from Burzio 1986:123, 127):

\footnotetext{
7 The functional vowel $a$ is glossed as A, while the clitic $l$ that occurs with auxiliaries, here used as an expletive, is glossed with $\mathrm{L}$.

$8 \quad$ Clitic pronouns also follow infinitives, as in Italian (7a) (example from Burzio 2006:122):
}

(i) A püdria esye tanta gent.

A could be-there many people

'There could be many people.' 
a. A y riva i client.

A there arrives the clients

'The clients are arriving.'

b. A y na riva tanti.

A there of.them arrives many

'Many of them are arriving.'

c. A y na ié tanti ntel negosi.

A there of.them is many in.the store

'There are many of them in the store.'

Burzio (1986:172,n.47) observes that enclitic and proclitic pronouns have different forms. In particular, he writes: "Clitic ne is realized as $n a$ when proclitic", suggesting, without however providing an example, that the partitive pronoun in enclitic position is ne (cf. A lé riva-ne tanti 'Many of them arrived').

I suggest that $/ a /$ in proclitic $n a$ 'of.them' in (26b-c) is an epenthetic vowel, inserted to syllabify the consonantal partitive clitic $/ \mathrm{n} /$ (which does not syllabify with the preceding locative $y$ in (26b), cf. * $A$ yn riva tanti, nor with the following verb in (26c), cf. *A y n'ié tanti ntel negosi). The proposal that /a/ in proclitic $n a$ in $(26 \mathrm{~b}-\mathrm{c})$ is an epenthetic vowel is supported by the quality of the vowel, which is identical to the functional vowel $a$ which precedes the locative clitic $y$ 'there'. Functional vowels are phonologically unmarked, on a par with epenthetic vowels (for the proposal that functional vowels realise functional heads of the clausal skeleton, see Cardinaletti and Repetti 2008, 2010a,b).

I instead take the vowel /e/ in enclitic pronouns ye 'there' and me 'me' in (25) as part of the lexical entry of the pronouns. These pronouns thus differ from e.g. Italian clitic pronouns $c i$ 'there', $m i$ 'me', etc., where final vowel $/ \mathrm{i} /$ is epenthetic, and are more similar to strong Italian pronouns like me or French weak/strong pronouns like moi, where the final vowels are part of their lexical entry (see section 2).

The Piedmontese facts can be analysed similarly to the Franco-Provençal facts discussed in section 3 above: the postparticiple pronouns are not clitic, but weak. They are morphologically more complex than preverbal clitic pronouns (cf. postverbal ye vs. proclitic $y$ in (25a) and (26a), respectively; postverbal ne vs. proclitic na, Burzio 1986:172,n.47) and occur in the postverbal space typical of weak pronouns in Romance languages.

Again, the question is what prevents the clitic form to occur in (25). The answer can be the same as the one provided in section 3: the proclitic position in (25) is taken by the clitic element $l$, which is instead absent in (26). Whatever the status of the $l$ element which occurs with auxiliaries (see Garzonio and Poletto 2011 for some discussion), it prevents the occurrence of a second proclitic element. ${ }^{9}$ Since a clitic pronoun is excluded, a weak pronoun is merged instead in the structure, complying with the generalisation in (12).

9 Note that the cooccurrence of $l$ with $a$ in (25) suggests that $a$ is not "counted" as a proclitic subject pronoun, in line with Cardinaletti and Repetti's (2010a,b) proposal that preverbal vowels in Northern Italian dialects are not subject clitic pronouns but realise functional heads of the clausal skeleton. This is confirmed 
The examples in (26b-c) further show that the $l$ element that occurs with auxiliaries differs from object clitics, which can cooccur in proclisis with simple verbs: see $y n a$ in (26b-c). The discussion of the type of clitic cluster formed by $y$ and $n a$, whether a true clitic cluster on a single functional head or a split clitic configuration where clitics are adjoined to two adjacent functional heads (see Kayne 1994, Cardinaletti 2008, 2010) is beyond the scope of this paper.

\section{Borgomanerese}

Another Piedmontese dialect which displays post-participle clitics is Borgomanerese, discussed by Kayne (1994:144,n.8) and Tortora (1997), (2002), (2014). In this dialect, things are even more challenging than in the dialects discussed so far. First, pronouns are never proclitic (and are enclitic also with finite verbs). Second, pronouns not only follow past participles (27a), as in the dialects seen in sections 3 and 4, but also follow postverbal clausal adverbs, such as piö in (27b), and the postverbal subject pronoun $m e ́$ in (27c):
a. I o vüsta-la.
I have seen-her
'I saw her.'
b. I o vüst piö-lla.
I have seen anymore-her
'I haven't seen her anymore.'
c. I dis mévvi.
I say me-to.you
'I tell you.'

The contrast between (27b) and (28a) shows that the pronouns occur in the clausal area between the adverbs corresponding to Italian più 'anymore' and sempre 'always', as schematized in (29) (see Tortora 2002, based on Cinque's 1999 adverbial hierarchy): ${ }^{10}$

by the fact that $a$, differently from $l$, can cooccur with one or two proclitic objects, as in (26).

10 Things are slightly more complex, given that the pronoun can move to the left if the verb also moves. Compare the finite verb in (28b) with the past participle in

(i) (examples from Tortora 2014:106):

(i) a. L Piero 1 à sempri mangià-llu.

the Piero he has always eaten -it

'Piero has always eaten it.'

b. Gianni 1 à mangià-llu sempri.

Gianni he has eaten -it always

'Gianni has always eaten it.'

These data are reminiscent of those found in Swedish, where the movement of weak pronouns to the left is contingent on the movement of the verb (cf.

Holmberg 1986, 1991) and may be taken to provide further evidence for the weak and not clitic status of the pronouns in Borgomanerese. 
(28) a *I mœngi sempra-la.

b. I mœngia-la sempri.

I eat-it always

'I always eat it.'

$$
\begin{array}{lr}
\text { piö }>\text { pronouns } & >\text { sempri } \\
\text { anymore } & \text { always }
\end{array}
$$

As shown in $(27 b, c)$, the pronouns are separated from the verb by adverbs and postverbal subjects. These data are problematic for the very robust crosslinguistic generalization that clitic pronouns can be separated from the verb only if they are higher than it, as schematized in (5)-(6) and repeated here in (30)-(31):
a. clitic
XP verb
(31)
a. * verb XP clitic
b. clitic
DP verb
b. * verb
DP clitic

The generalization concerning enclisis was formulated by Rizzi (2000:118) as in (32):

(32) If the verb moves to a position past the landing site of the clitic, it carries the clitic along.

The Borgomanerese facts in (27) can be made compatible with the generalization in (31) if it is suggested that the postverbal pronouns are weak and not clitic. They appear in the low clausal area hosting weak pronouns in Romance languages (see section 2 above). Note that the two orders 'verb - adverb - weak pronoun' and 'verb - subject - weak pronoun' attested in Borgomanerese are also found with Italian loro. See (10b) and (11) above.

Some phonological properties can provide an argument for the weak status of the post-participle pronouns in Borgomanerese.

First consider the fact that preverbal and postverbal pronouns have different morphological forms, the former smaller than the latter, similarly to what we have seen in the other Piedmontese dialects discussed in section 4 . This can be shown on the basis of the pronoun corresponding to Italian si and French se. As in Italian and French, this element can be either impersonal or reflexive. In Borgomanerese, the former is proclitic (as in $(33 \mathrm{a}, \mathrm{b})$ ), the latter is postverbal (as in (33c)) (examples from Tortora 2014:130-131):

a. As môngia bej chilonsé.

si eats well here

'One eats well here.'

b. Sa sta bej chilonsé.

si is well here

'It's nice here.'

c. Al vônga-si.

he sees -himself

'He sees himself.' 
Tortora (2014:130-131 and n. 44) suggests that the underlying form of the impersonal subject clitic is $s$, and the alternating forms $a s / s a$ in $(33 \mathrm{a}, \mathrm{b})$ are phonologically constrained: the epenthetic vowel [a] is inserted before or after the consonant depending on the prosodic context (similarly to what happens in other Northern Italian dialects, see Cardinaletti and Repetti 2008:530-531).

Consider now the postverbal reflexive form in (33c). It contains the final vowel [i], on a par with other person clitics, see $v i$ 'you' in (27c). Differently from Tortora, who analyses both impersonal and reflexive elements as clitic, I consider reflexive si as weak, and take the final vowel [i] to be part of its lexical entry (see section 2 above).

Consider now the form of the verbal host. We have seen above that in (27a), the verb takes a final vowel /a/ which is not present when the verb does not immediately precede the pronoun, as in $(27 \mathrm{~b})$. The examples are repeated here as (34):
a. I o vüsta-la.
I have seen -her
'I saw her.'
b. I o vüst piö -lla.
I have seen anymore-her
'I haven't seen her anymore.'

Final /a/ could be analysed as the expression of past participle agreement. This would however mean that agreement takes place with a(n adjacent) postverbal pronoun, an unprecedented situation in modern Romance languages in which agreement always takes place with raised elements, either clitic pronouns or wh-elements (see Belletti 2006 for an overview). ${ }^{11}$

Note that the phenomenon is also found with finite verbs and adverbs, whose final /i/ is replaced by /a/ when they precede a pronoun, as in (36) (data from Tortora 2002:726-728):
I bring the cake
'I bring the cake.'
a. I porti la torta
b. I porti denti la torta.
I bring inside the cake
'I bring the cake inside.'
(36) a. I porta-la.
I bring-it
'I bring it.'
b. I porti denta-la.
I bring inside it
'I bring it inside.'

The analysis of final /a/ as a reflex of object agreement is even less plausible with finite verbs and adverbs. No object agreement with finite verbs and adverbs is ever found in Romance languages, and Indoeuropean more generally. The data in (36) confirm that an alternative analysis of final /a/ is necessary.

I suggest that the final vowel is part of the postverbal pronoun itself. If this is correct, the sequences in $(27 \mathrm{a}),(28 \mathrm{~b})$, and $(36 \mathrm{a}, \mathrm{b})$ should be analysed as (37a,b,c,d), respectively:

\footnotetext{
11 Past-participle agreement with the following complement was possible in Old Italian (see Egerland 1996, Salvi 2010).
} 

a. I o vüst-ala.
b. I mœngi-ala.
c. I port-ala.
d. I porti dent-ala.

In other words, the feminine pronoun is ala, a bisyllabic element which can only be analysed as a weak pronoun, clitic pronouns being monosyllabic (see section 2). The initial /a/ of the pronoun drops if the preceding word ends in a stressed vowel, as in (34b).

Final vowel $/ \mathrm{a} /$ on the verb is also found with accusative masculine pronouns, as in (38a) (taken from Tortora 2002:731). Parallel to (37), the analysis of (38a) suggested here is $(38 b)$ :
a. I trata-lu mal.
'I treat him badly'
b. I trat-alu mal.

Note that with the partitive pronoun corresponding to Italian ne, a different final vowel, $/ \mathrm{u} /$, is found on finite verbs and past participles (data from Tortora 2002:730 and 1997:78,n.49, respectively):
a. I mœngiu-nu.
I eat of.them
'I eat some of them.'
b. I o vustu-nu tre.
I have seen of.them three
'I saw some of them.'

On a par with the vowel /a/, the vowel /u/ could be taken to be part of the verbal inflection. This analysis would however imply that (i) the finite verb agrees with the indefinite object, (ii) agreement is sensitive to the accusative vs. partitive status of the pronominal complement $(/ \mathrm{a} / v s$. /u/, respectively), (iii) the verb carries the same object agreement inflection when it is finite (39a) or infinitive (39b), which are to our knowledge three other unprecedented agreement configurations in the Romance languages.

As we have done with the vowel /a/ above, the vowel / $\mathrm{u} /$ can be taken to be part of the pronoun itself, unu. The data in (39) should be analysed as follows:
a. I mœngi-unu.
b. I o vust-unu tre.

Again, the bisyllabic nature of the indefinite pronoun $u n u$ points to its analysis as a weak pronoun, as we suggested above. The weak indefinite $u n u$ can be taken to have a parallel status as the English indefinite one in (41), which can also be considered to be a weak pronoun:

(41) I have seen three nice ones. 
One does not receive sentence stress, which falls on the quantifier (cf. I have seen three nice ones) and behaves in this respect on a par with weak personal pronouns, with which clause stress falls on the verb (cf. I saw him). The difference between English one and Borgomanerese unu lies in their syntactic distribution, ипu being extracted out of the quantifier phrase and moved to the position of weak pronouns in the language.

Note that Tortora (2002:728, fn.5) considers the change from /i/ to [a] in the final vowel of the finite verb and the preposition in (35)-(36) as a phonological phenomenon. She however does not discuss the [a] that appears on past participles as in (27a), nor does she observe the change from /i/ to [u] in (39). If the phenomenon were phonological, it would be hard to account for the different vowel output, namely [a] $v s$. [u]. It would again be an unprecedented phenomenon that a phonological rule depends on the morphological case of the pronoun, accusative $v s$. partitive, respectively. We conclude that a syntactic analysis of the phenomenon is more adequate than a phonological approach.

In a more detailed analysis of the final vowels which appear on the hosts in the presence of enclisis, Tortora (2014:186-191) suggests that two vowelchange phenomena are indeed observed in this dialect: a "vowel reduplication" strategy, where the final vowel of the host is the same as the vowel of the clitic pronoun, and the "change to [a]" strategy, where the final vowel of the host is invariably [a]. The sentences in (42), taken from Tortora (2014:182) and (2014:189) respectively, and the sentences in (43), taken from Tortora (2014:187) and (2014:189) respectively, show that the two phenomena are in free variation with different clitic forms:

(42) a. I bütti dentu-lu.

b. I bütti denta-lu.

I put inside-it

'I'm putting it inside.'

(43) a. I môngiu-nu.

I eat-of.them

'I eat some of them.'

b. Quônta tal môngia-nu?

how much you eat-of.it

'How much of it are you eating?'

In our proposal, the vowel does not belong to the (verbal or adverbial) host, but to the pronoun itself. Whatever the real nature of the two phenomena, they would affect the initial vowel of the weak pronoun, which makes it bisyllabic (for initial vowels in weak pronouns, see section 2).

Analysing postverbal pronouns as clitic, Tortora (1997:23,n.14) suggests that in cases like (27b), the geminate consonant displayed by the pronoun is due to the presence of a preceding stressed vowel on the adverb piö, a phonological phenomenon similar to Raddoppiamento Sintattico in Italian. ${ }^{12}$ This phenomenon

12 Note that the same should be said for the stressed postverbal subject in (27c). 
is not incompatible with the weak status of the pronoun, however, since Raddoppiamento Sintattico also applies to the Italian weak pronoun loro:

(44) Gianni parlò [11]oro

'Gianni spoke to them'.

The analysis provided here for the Borgomanerese dialect implies that this dialect does not possess (object) clitic pronouns at all. ${ }^{13}$ That some Romance languages do not possess clitic pronouns is not unprecedented. Benincà and Poletto (2005) claim that Rhaeto-Romance dialects only display strong pronouns, which occur after the verb:

Vus amflayas bec el.

you find not it

Note that their proposal should be slightly refined. Differently from what is assumed by Benincà and Poletto (2005:228), the pronoun el in (45) cannot be analysed as a strong pronoun because it has [-human] reference (as suggested by the gloss 'it'). The Rhaeto-Romance pronoun $\mathrm{el}$ in (45) should rather be analysed as a weak pronoun, which is compatible with [-human] referents (see (16) above). A more precise characterisation of the Rhaeto-Romance dialects discussed by Benincà and Poletto (2005) is thus to say that they only possess weak and strong pronouns (and lack clitic pronouns).

Borgomanerese turns out to be a language of the same type as the RhaetoRomance dialects: it lacks clitic pronouns and only possesses weak and strong pronouns. The difference with Italian and the other Romance varieties which possess clitic pronouns is thus lexical in nature and does not involve variation in the syntax of clitic pronouns, a welcome result under current hypotheses on language variation.

\section{Conclusions}

In this paper, I have discussed cases of apparent encliticization to participles in Romance varieties. Some of the languages discussed also allow for postverbal pronouns to be separated from the verb by other lexical material (an adverb or a postverbal subject pronoun). I have shown that both configurations are only apparent cases of encliticization. Rather, the postverbal pronouns can be analysed as weak pronouns, which appear in the low clausal space after the past participle and may occur independently of the verb.

13 Borgomanerese only possess subject clitic pronouns, including impersonal $s$ (see (33) above). 


\section{References}

Belletti, Adriana 2006. "(Past) participle agreement". In M. Everaert and H. van Riemsdijk (eds.), The Blackwell Companion to Syntax, vol. III, 491-521. Oxford: Blackwell. http://dx.doi.org/10.1002/9780470996591.ch48

Benincà, Paola and Poletto, Cecilia. 2005. "On some descriptive generalizations in Romance". In G. Cinque and R. S. Kayne (eds.), Handbook of Comparative Syntax, 221-258. Oxford: Oxford University Press. http://dx.doi.org/10.1093/oxfordhb/9780195136517.013.0006

Berendsen, Egon. 1986. The Phonology of Cliticization. Dordrecht: Foris. http://dx.doi.org/10.1515/9783111403144

Burzio, Luigi. (1986). Italian Syntax. Dordrecht, Reidel.

Cardinaletti, Anna. 1991. "On pronoun movement: The Italian dative loro". Probus 3.2: 127-153.

http://dx.doi.org/10.1515/prbs.1991.3.2.127

Cardinaletti, Anna. 1994. "On the internal structure of pronominal DPs". The Linguistic Review 11: 195-219. http://dx.doi.org/10.1515/tlir.1994.11.3-4.195

Cardinaletti, Anna. 2008. "On different types of clitic clusters". In C. De Cat and K. Demuth (eds.), The Bantu-Romance Connection, 41-82. Amsterdam: Benjamins. http://dx.doi.org/10.1075/la.131.06car

Cardinaletti, Anna. 2010. "Morphologically complex clitic pronouns and spurious se once again". In V. Torrens, L. Escobar, A. Gavarró and J. Gutiérrez (eds.), Movement and Clitics: Adult and Child Grammar, 238-259. Newcastle: Cambridge Scholars Publishing.

Cardinaletti, Anna and Lori Repetti 2008. "The Phonology and Syntax of Preverbal and Postverbal Subject Clitics in Northern Italian Dialects". Linguistic Inquiry 39.4, 523-563.

http://dx.doi.org/10.1162/ling.2008.39.4.523

Cardinaletti, Anna and Lori Repetti. 2010a. "Functional vowels in main questions in Northern Italian dialects". In R. Bok-Bennema, B. Kampers-Manhe and B. Hollebrandse (eds.), Romance Languages and Linguistic Theory 2008. Selected Papers from 'Going Romance' Groningen 2008, 37-58. Amsterdam: Benjamins. http://dx.doi.org/10.1075/rllt.2.04car

Cardinaletti, Anna and Lori Repetti. 2010b. "Preverbal vowels in wh-questions and declarative sentences in Northern Italian Piacentine dialects". In S. Colina, A. Olarrea and A. M. Carvalho (eds.), Romance Linguistics 2009 Selected Papers from the 39th Linguistic Symposium on Romance Languages (LSRL), Tucson, Arizona, March 2009, 353-368. Amsterdam: Benjamins. http://dx.doi.org/10.1075/cilt.315.21 car

Cardinaletti, Anna. and Ur Shlonsky. 2004. "Clitic positions and restructuring in Italian”. Linguistic Inquiry 35: 519-557. http://dx.doi.org/10.1162/0024389042350523 
Cardinaletti, Anna and Michal Starke. 1996. "Deficient Pronouns: A View from Germanic. A Study in the Unified Description of Germanic and Romance". In H. Thráinsson, S. D. Epstein and S. Peter (eds.), Studies in Comparative Germanic Syntax Volume II, 21-65. Dordrecht: Kluwer. http://dx.doi.org/10.1007/978-94-010-9806-9_2

Cardinaletti, Anna and Michal Starke. 1999. "The typology of structural deficiency: A case-study of the three classes of pronouns". In H. van Riemsdijk (ed.), Clitics in the languages of Europe, EALT/EUROTYP 205, 145-233. Berlin: Mouton de Gruyter. http://dx.doi.org/10.1515/9783110804010.145

Chenal, Aimé. 1986. Le franco-provençal valdôtain. Aoste: Musumeci.

Cinque, Guglielmo. 1999. Adverbs and Functional Heads. Oxford: Oxford University Press.

Corver, Norbert and Denis Delfitto. 1999. On the nature of pronoun movement. In H. van Riemsdijk (ed.), Clitics in the languages of Europe, EALT/EUROTYP 20-5, 799-861. Berlin: Mouton de Gruyter.

Egerland, Verner. 1996. The Syntax of Past Participles. A Generative Study of Nonfinite Constructions in Ancient and Modern Italian. Lund: Lund University Press.

Garzonio, Jacopo and Cecilia Poletto 2011. "I clitici di ausiliare nelle varietà piemontesi”. In J. Garzonio (ed.), Studi sui dialetti del Piemonte, Quaderni di lavoro ASIt n. 13, Padua, 117-134.

Holmberg, Anders. 1986. Word Order and Syntactic Features in the Scandinavian Languages and English. Stockholm: University of Stockholm. http://dx.doi.org/10.1017/s0332586500001931

Holmberg, Anders. 1991. "The distribution of Scandinavian weak pronouns". In H. van Riemsdijk and L. Rizzi (eds.), Clitics and their Hosts, Eurotyp Working Papers, vol. 1, 155-173.

Jaeggli, Osvaldo. 1982. Topics in Romance Syntax. Dordrecht: Foris. http://dx.doi.org/10.2307/414197

Kayne, Richard S. 1975. French Syntax. Cambridge, Mass.: MIT Press.

Kayne, Richard S. 1991. "Romance clitics, verb movement and PRO", Linguistic Inquiry 22.4: 647-686.

Kayne, Richard S. 1994. The Antisymmetry of Syntax. Cambridge, Mass.: MIT Press.

Kayne, Richard S. 2000. "Person morphemes and reflexives in Italian, French, and related languages". In R. S. Kayne, Parameters and Universals, 131162. Oxford: Oxford University Press (also in C. Tortora (ed.), 2003, The Syntax of Italian Dialects, 102-136. Oxford: Oxford University Press).

Keller, Hans-Erich. 1958. Etudes linguistiques sur les parlers valdôtains, Romanica Helvetica 66. Berne: Francke.

Ordóñez, Francisco and Lori Repetti 2006. "Stressed Enclitics?". In J.-P. Montreuil (ed.), New Analyses on Romance Linguistics: Volume II: Phonetics, Phonology and Dialectology, 167-181. Amsterdam \& Philadelphia: John Benjamins.

Ordóñez, Francisco and Lori Repetti 2014. "On the morphological restrictions of hosting clitics in Italian and Sardinian dialects". L'Italia Dialettale LXXV: 173-199. 
Rizzi, Luigi. 1982. Issues in Italian Syntax. Dordrecht: Foris. http://dx.doi.org/10.1515/9783110883718

Rizzi, Luigi 2000. "Some notes on Romance cliticization”. In Comparative Syntax and Language Acquisition, 96-121. London: Routledge.

Roberts, Ian 1993. "The nature of subject clitics in Franco-Provençal Valdôtain". In A. Belletti (ed.), Syntactic Theory and the Dialects of Italy, 319-353. Turin: Rosenberg \& Sellier.

Salvi, Giampaolo. 2010. "L'accordo". In G. Salvi and L. Renzi (eds.), Grammatica dell'italiano antico, 547-568. Bologna: il Mulino.

Schroten, Jan. 1992. "On Spanish definite determiners: Personal pronouns and definite articles". Recherches de Linguistique Romane et Française d'Utrecht XI: 9-24.

Starke, Michal. 1993. En deuxième position en Europe Centrale. Mèmoire de licence, Université de Genève.

Tortora, Christina. 1997. The Syntax and Semantics of the Weak Locative. PhD dissertation, University of Delaware.

Tortora, Christina. 2002. "Romance enclisis, prepositions, and aspect". Natural Language and Linguistic Theory 20: 725-758.

Tortora, Christina. 2014. A Comparative Grammar of Borgomanerese. New York: Oxford University Press.

http://dx.doi.org/10.1093/acprof:oso/9780199945627.001.0001 